\title{
Fikih kerukunan dalam naskah Serat Waosan Puji
}

\author{
Zakiyah
}

\author{
Penditi padaBalai LitbangAgama \\ KemeterianAgama Semarang \\ zaki_smart@yahoocomzaki_mgill@yahoocaid
}

This paper focus on a manuscript entitled Serat WaosanPuji. This manuscript is saved at WidyaBudaya library of Yogyakarta kingdom. D ata is analyzed using reception theory and sociology of letter. Finding of this research shows that physically this manuscript is in a good condition and readable. This manuscript consists of several texts which tell about do'a (prayer), pillar of faith, pillar of Islam, theology, name of verses in the Q uran, Ki Purwadaksina's teaching, SeratNiti Snti, and Serat Nitipraja Meanwhile, the teaching of harmony is stated in three pupuh (chapter) namely pupuhdhandhanggilaconsisting of Ki Purwadaksina's teaching, pupuhdhandhanggula consisting of Serat Nitisuti, pupuhdhandhanggula consisting of satititipraja Among all of those harmonius teaching are (1) philosophy of life comprising pandhita lami, pandhita boja karama, and pandhita umarshandu or pandhita gunung (2) things which should be avoided namely pandhita sipat, limpad, prakkensanghyang nggithongumosand tavangbrama (3) lesson of life interaction such as empathy, respecting others, humble and others, (4) asthabrata, (5) principle of king.

\section{Keywords: Serat naosan puji; Hammy; Isam Java}

\section{Pendahuluan}

Jawa merupakan salah satu daerah dengan tradisi tulis yang sudah berumur ratusan tahun dan telah menghasilkan naskah dengan jumlah yang sangat banyak. Th. Pegued (19671980) mengatakan "sastra Jawa yang sampai kepada kita dalam bentuk naskah hanya merupakan sebagian kecil dari keseluruhan tulisan yang dihasilkan oleh para pengarang Jawa selama berabad-abad, mulai dari masa pra Islam sampai dengan abad ke-19 (Pigeaud, 1967-1980 II, 1 seperti dikutip oleh Loir dan Fathurahman, 1999: 95). 
Naskah-naskah Jawa tersebut mengandung beragam ajaran di antaranya tentang kerukunan. Hal ini tidak terlepas dengan nilai-nilai ajaran yang ada pada masyarakat, di antara ajaran tersebut adalah tepa sdira, yakni perasaan menghormati orang lain dan menghayati perasaan orang lain. D engan tepa selira seseorang akan mengetahui unggah unggih atau tata krama pergaulan dalam masyarakat. Di antara rasa hormat itu semestinya ditujukan kepada orang yang lebih tua, yakni tua dengan maknanya yang luas, tua umur, tinggi derajat-pangkat, kekayaan, lebih tinggi ilmunya (cendekiawan dan ulama) (Raqib, 2007: 57-58).

Ajaran ungggh-ungghhtersebut tidak terbatas pada ungcgh-ungguhingbasa(tata krama bahasa), tetapi juga berarti sopan santun. D engan adanya unggahungguhingbasa, seseorang diharapkan untuk menggunakan bahasa yang sesuai dan tepat, sehingga tidak akan menimbulkan perasaan tidak enak saat berkomunikasi. Karena, penggunaan ngkokrama dalam masyarakat Jawa merupakan bagian dari norma sosial, yang berfungsi untuk menunjukkan rasa hormat dan keakraban. Selain itu, ngoko-kromo juga berfungsi sebagai pengatur jarak sosial (Jandra, 2007: 50-51).

Salah satu naskah yang penting dan relevan dengan tema kerukunan untuk dikaji adalah naskah Waosanpuii. Naskah ini disimpan di perpustakaan Widya Budaya Keraton Yogyakarta, diduga mengandung nilai-nilai luhur terkait dengan tema kerukunan kehidupan bermasyarakat. Berdasarkan pemikiran tersebut maka penelitian ini fokus kepada tiga masalah yaitu; (a) Bagaimana kondisi naskah SeratWaosanPuji, (b) Apa isi naskah Serat WaosanPuji, (c) Bagaimana nilai-nilai kerukunan bermasyarakat yang terkandung di dalam naskah Serat WaosanPuji.

Beberapa studi telah membahas tentang naskah-naskah keraton baik naskah babadmaupun seat yang tersimpan di perpustakaan Widya Budaya keraton Yogyakarta. Syamsul Hadi, dkk. (2006) mengkaji empat seat yang ada di perpustakaan tersebut, meliputi Serat Sittin dengan kode W.306 atau C.59, Serat Jasmaningat dengan kode koleksi C.65 atau BH. 277 dan nomor Girardet 43005, Serat Sifatul Wijra, dan Serat Bustam Keempat naskah tersebut di alihaksarakan dari huruf Jawa ke aksara latin, diterjemahkan dari bahasa Jawa ke bahasa Indonesia, dan dianalisis dengan menggunakan konsep-konsep Islam. SeatSittindikaji dengan melihat aspek akidah dan aspek fikihnya. Serat Jasmaningat dikaji dan dianalisis elemen tasawufnya. Sementara Serat Sifatul Wijra dikaji dengan menggunakan teori resepsi dan melihat aspek akidahnya. 
Serat Ngaboul Suka koleksi Perpustakaan Widya Budaya telah dikaji oleh Djoko Suryo pada tahun 2007. Ia membahas ajaran nilai-nilai etika moral sosial keagamaan bagi calon raja dan pemimpin yang terkandung dalam saat tersebut. Naskah ini ditulis pada tahun 1847 oleh Sultan Hamengkubuwono ke-5, berisi tentang seorang tokoh bernama Ngabdul Suko dengan karakter murah hati, dermawan dan selalu memegang prinsip hidupnya. Serat ini merupakan jenis piwulang(Jawa). Ajaran-ajaran tersebut terbungkus dalam tiga bagian cerita, pertama kisah tentang Ngabdul Suko dan keluarganya. Kedua dan ketiga berisi kisah putra dari Ngabdul Suko bernama Raden Kasim yang diramal akan menjadi raja.

Suyami (2004) meneliti naskah Serat Piimbonkoleksi Keraton Yogyakarta dengan kode D 6/ M269/ Bh139. Ia mengkaji isi dan membahasnya dari sisi mistiknya. Sebagian besar kandungan naskah bercerita tentang ramalan, di antaranya adalah ramalan/ perwatakan alam berdasarkan perhitungan jatuhnya hari pada tanggal 1 Syura, ramalan/ perwatakan wuku, ramalan perwatakan dan nasib baik manusia berdasarkan wuku saat kelahirannya, ramalan alam dan terjadinya gempa, ramalan/ nahas pada setiap bulan, ramalan hari baik dan buruk, ramalan nasib manusia berdasarkan bulan pelaksanaan perpindahan rumah dan perkawinan, ramalan tentang rijal ghaib, ramalan tentang saat yang baik untuk melakukan sesuatu berdasarkan pada tiap hari, dan ramalan-ramalan lainnya. Di samping itu, terdapat pula kisah leluhur Nabi Muhammad sampai ke Nabi Adam serta keturunannya sampai Raden Muhammad Santri di Surabaya.

Marsono (2004) mengkaji Serat Waosan Puji kode W.322 yang disimpan di perpustakaan Widya Budaya Keraton Yogyakarta. Ia melihat aspek akulturasi Islam dan Jawa dalam isi teks Waosan Puji. Menurutnya, naskah ini mengandung beberapa ajaran Islam seperti, rukun iman, rukun Islam, dan surat-surat dalam al-Q ur'an. Pun demikian, terdapat pula konsepkonsep Jawa Islam, misalnya tentang konsep astabratha dan nitipraja.

D jamil (2000) membahas beberapa karya sastra pesisiran Jawa yang paling mendapatkan pengaruh Islam seperti dalam naskah Wejangan Syeh Bani. Naskah tersebut diketahui berisi tentang ajaran tasawuf al-G hazali dan Junaid al-Baghdadi yang bercorak sunni; inti dari wejangan/ nasehat syeh Bari pada murid muridnya adalah untuk tidak mengikuti ajaran tasawuf falsafi. Sementara naskah sastra pedalaman lebih bercorak mistik seperti tergambarkan dalam SeratCdoddk karya Pujangga Yasadipura 1; dalam naskah ini disebutkan 
bahwa untuk mencapai kebahagiaan hidup, manusia harus menyatu dengan Tuhan yang disebut dengan ManumggglingKawula Gusti. Karya sastra Jawa lainnya misalnya adalah Wirid HidayatJati ditulis oleh R.Ngb.Ranggawarsita yang berisi tentang tata cara untuk mencapai kemanunggalan dengan Tuhan. D alam karya ini terdapat elemen-elemen Islam yakni dapat dilihat dari penggunaan beberapa istilah tasawuf Islam seperti wahblat al-ucijud, ittihbd, holul dan lainnya (Djamil, 2000: 162-167).

D ari beberapa hasil penelitian tersebut tidak terdapat kajian mengenai Serat WaosanPuji terkait dengan nilai-nilai kerukunan. Oleh karenanya, penelitian ini berbeda dengan kajiankajian terdahulu.

Penelitian ini menggunakan framework sebagai berikut. Pertama, Untuk mendesknipsikan kondisi fisik naskah yang diteliti menggunakan ilmu bantu kodikologi, yaitu suatu ilmu yang membahas tentang buku tulisan tangan (naskah) (D ain, 2007), dengan melihat sisi fisik atau bentuknya yakni meliputi antara lain, nomor naskah, ukuran kertas/ lontar atau alas tulis lainya, jumlah halaman/ lempir, jumlah baris per halaman, jenis aksara, iluminasi, warna tinta dalam naskah, kolofon dan lainnya (Kramadibrata, 2007).

Kedua, untuk mengungkap Isi atau materi dalam teks Serat WaosanPüi maka interpretasi adalah salah satu cara dalam mengungkapkan makna. Dalam hal ini akan dimanfaatkan teori resepsi, yakni yang memandang penting peran pembaca (peneliti) dalam memberikan makna teks sastra (Hadi dkk, 2005: 150). Interpretasi di sini dimaknai sebagai cara untuk melihat isi, membaca simbol-simbol dan memaknai isi pesan dalam teks. Teks ditempatkan pada posisi otonom di mana teks tersebut tidak lagi tergantung pada penggagas awalnya. Hal ini mengacu kepada pendapat Ricour (1981) yang mengemukakan tulisan karya sastra mampu melampaui situasi dan kondisi masa diproduksinya sebuah tulisan, serta mampu memasuki ruang dan waktu yang berbeda (Ricour, 1981, seperti dikutip oleh Faruk, 2010: 48). Namun demikian, pada saat yang sama, sebuah karya sastra tidak bisa dilepaskan dari dunia sosial yang melingkupinya. Dalam teori sosiologi sastra disebutkan, di dalam karya tulisan terssebut ditemukan gambaran mengenai manusia, relasi sosial, ruang dan waktu yang serupa dengan yang ada di dalam kenyataan (Faruk, 2010: 47).

Sebagaimana sosiologinya Weber tentang tindakan sosial, sastra juga paling tidak mengandung salah satu dari tindakan sosial berikut; (a) tindakan yang berorientasi tujuan 
yakni sastra merupakan tindakan reflektif rasional dengan tujuan yang jelas, (b) tindakan berorientasi nilai, dan (c) tindakan berorientasi nilai tradisonal, maksudnya sastra merupakan tindakan yang dilakukan secara tradisional dan tujuannya sudah diterima secara tradisional (Faruk, 2010: 54-55).

A pabila melihat sebagian isi dari SeratWaosanPuii, naskah ini dapat dikategorikan sebagai sastra keagamaan dan lebih khusus lagi "sastra kitab". Merujuk pada pendapatnya Fang (1987) yang mengatakan, sastra keagamaan atau sastra Islam adalah karya sastra yang mengandung unsur Islam. D emikian pula Chamamah-Soeratna (1980) menyebutkan sastra keagamaan dibagi menjadi tiga corak, yaitu (a) sastra rekaan berupa cerita fiksi yang mengungkapkan tokoh-tokoh Islam rekaan, (b) sastra sejarah benisi tentang sejarah penyebaran Islam dan raja-raja Islam, dan (c) sastra kitab adalah karya sastra yang berisi tentang masalah keislaman (Hadi dkk, 2005, 151). Namun demikian, apabila melihat isinya secara keseluruhan, naskah ini dapat dikatakan sebagai kepustakaan Islam Kejawen yaitu salah satu kepustakaan Jawa yang memuat perpaduan tradisi Jawa dengan unsur-unsur Islam. Nama yang digunakan untuk menyebut kepustakaan Islam K ejawen ini adalah primbon, wirid dan suluk. Adapun wirid dan suluk merujuk pada naskah yang membahas ajaran tasawuf atau mistik Islam. Sedangkan primbon isinya mencakup berbagai macam ajaran yang berkembang dalam tradisi Jawa, seperti ngdmupdung ramalan, gunaguna, juga memuat aspek ajaran Islam (Simuh, 1988: 2-3). Jadi naskah Serat Waosan Püi merupakan sebuah pimbon

Adapun untuk membahas fikih kerukunan di dalam teks digunakan konsep-konsep harmoni di dalam Islam dan Jawa. Hal ini penting karena Serat Waosan Puji mengandung tidak hanya ajaran Islam tetapi juga nilai-nilai Jawa. Di dalam Islam, terdapat konsep ukhuwah (persaudaraan), meliputi (a) ukhumahIsamiyjahyakni persaudaraan sesama muslim, (b) ukhumah watanniyyahyaitu kerukunan hidup sesama bangsa, (c) ukhumahbashaniyah adalah kerukunan sesama manusia dimanapun ia berada, (d) ukhumah 'alamiyah, merupakan keharmonisan dengan sesama penduduk alam semesta seperti tumbuhan dan binatang, tanah, air dan lainnya (Roqib, 2007: 21-22). Kemudian isi teks tersebut dilihat dengan konsep-konsep kerukunan di dalam ajaran Jawa. Simpul-simpul kerukunan tersebut tercermin di dalam beberapa hal, misalnya (b) bahasa Jawa, di mana di dalam tuturan Jawa tersirat nilai-nilai kerukunan, (c) ajaran kearifan orang Jawa, (c) tradisi orang Jawa berupa beberapa upacara 
atau cremny, contohnya, sdamłandan acara yang lainnya (Roqib, 2007: 47-49).

Penelitian ini merupakan penelitian kualitatif. Dalam studi ini diteliti kondisi fisik naskah dan ditelusuri riwayat naskah dengan melihat kolofon serta catatan-catatan lainnya, kemudian dilakukan analisis terhadap isi teks terkait dengan nilai-nilai kerukunan dengan interpretasi dan sosiologi sastra. Sasaran penelitian adalah naskah Serat Waosan Puji yang tersimpan di Perpustakaan Widya Budaya Keraton Yogyakarta.

\section{Deskripsi naskah Serat Waosan Puji}

Naskah Seat Waosan Puji yang diteliti adalah naskah dengan kode D.10 / M259 / Bh.19 yang disimpan di perpustakaan Widya Budaya keraton Ngayogyakarta Hadiningrat. Menurut Lindsay dkk (1994), naskah ini diduga merupakan salinan dari naskah W.321 dengan judul "Serat Kaklempakan". Naskah lain yang serupa juga ada yakni koleksi pribadi T.E Behrend yang didapatnya dari Dr. Soebardi di Canbera, yang berasal dari kesultanan Hamengkubuwono ke-5.

Di dalam teks pupuhpertama disebutkan naskah mulai ditulis pada hari Selasa Kliwon, jam sebelas siang, tanggal 25 Jumadilakir 1781, tahun Jimawal, musim D estha (kesebelas), wuku kurantil, lambang klawu, bersamaan dengan tahun masehi tanggal 5 April 1853. D isebutkan dalam naskah, saat serat ini ditulis yang sedang menjadi penguasa memakai bintang Leo dari Nederland, penguasa tersebut adalah raja dari Kraton Yogyakarta di Jawa. Naskah selesai ditulis pada hari Selasa Kliwon.

Keterangan waktu selesai penulisan terdapat pada bagian akhir naskah yang menyebutkan naskah diselesaikan pada hari Selasa kliwon jam sembilan pagi, tanggal 5 Rabiulawal tahun Je 1782. Lambangnya K lawu, musim keenam, wuku Julungwangi. Bertepatan dengan bulan belanda, D esember 1851 tanggal 6. Kemungkinan tentang tahun tersebut telah terjadi kesalahan penulisan karena naskah mulai ditulis tahun 1853, bisa jadi tahun yang seharusnya tertulis adalah 1854 .

Naskah dalam kondisi baik, teks dapat dibaca dengan jelas. Teks ditulis di atas bahan kertas eropa, terdapat cap kertas dan laid lain di dalamnya. Sampul naskah dari kertas tebal warna coklat. Teks ditulis dengan tinta hitam, dengan aksara dan bahasa Jawa. Teks berupa tembang macapat. Ukuran naskah; panjang 33,6 cm, lebar 20,5 cm. Pada halaman 1 dan 2 
teks ditulis di dalam bingkai selebar 8,6 cm dengan margin luar, margin dalam $3 \mathrm{~cm}$, margin bawah dan atas masing-masing $10 \mathrm{~cm}$. Sedangkan pada halaman 3 sampai halaman 127 teks ditulis tanpa bingkai dengan margin luar $5,2 \mathrm{~cm}$, margin dalam 1,8 $\mathrm{cm}$, margin bawah 4,5 cm, dan margin atas 5,5 cm. Jumlah halaman naskah 127.

Naskah Serat Waosan Puji berisi beberapa macam teks. Nampaknya naskah ini merupakan kumpulan beberapa nukilan teks dari beberapa naskah lain. Hal ini terlihat dari beragamnya tema yang dikandung dan isi cerita tidak berkaitan antara satu teks dengan teks lainnya. Masing-masing teks diawali dengan sub judul berupa nama tembang dan beberapa di antaranya disebutkan tentang judul teks tersebut. D ari penyebutan judul tersebut dapat dilacak bahwa teks yang dimaksud diduga bersumber dari naskah lain misalnya, naskah Nitipraja dan naskah Nitisnti, kedua teks tersebut dipaparkan secara singkat di dalam Serat Waosan Puji. Di dalam buku Kitab Jawa Kuno juga dimuat dua terjemah naskah Serat Nitiparaja dan naskah Seat Nitisnti. Secara umum isi kedua naskah, baik yang ada di dalam Serat Waosan Puji maupun yang ada di dalam buku, memiliki kemiripan (Purwadi 2009). Namun sayangnya buku tersebut tidak menyebutkan sumber serta asal naskah, sehingga sulit untuk melacak naskah aslinya.

Sementara teks yang memuat tentang hari-hari baik, sifat-sifat baik perempuan, waktuwaktu yang baik, watak hari dan lainnya mempunyai kemiripan dengan naskah-naskah lain seperti naskah primbon, salah satunya adalah kitab piimbon Bealjemur adammakno(Noeradyo 1994).

Semua teks dalam naskah Serat Waosan Puji ini dibingkai dengan nama tembang macapat dengan urutan sebagai berikut; mijil, dhandhanggula, asmaradana, dhandanggula, asmaradana, dhandanggila, sinom, dhandhanggila, asmaradana, kinanthi, asmaradana, sinom. pangkur, dhandhanggila, asmardana, maskumambang mijil, puang asmaradana, sinom asmaradana, sinom asmaradana, dhandhanggula, dhandhanggila, dan dhandhanggula.

Berikut ini adalah isi ringkas dari Serat Waosan Puji; tentang doa-doa; rukun iman, rukun Islam dan tauhid; nama-nama surat dalam al-Q ur'an; ajaran Ki Purwadaksina; nasehat Rasulullah kepada putrinya, ramalan-ramalan, firasat dan watak manusia, nama-nama makhluk halus, hari-hari baik, serat Niti Snti, dan Serat Nitipraja. 


\section{Pesan keagamaan dalam Serat Waosan Puji}

Aspek ajaran keagamaan yang ada di Serat Waosan Puji lebih banyak kepada ajaran-ajaran ke-Islaman. Ajaran tentang ketuhanan (tauhid) dengan jelas digambarkan di dalam teks Serat WaosanPuji. D isebutkan rukun Iman yang pertama adalah percaya kepada Allah. Kemudian dijelaskan tentang beberapa sifat Allah yaitu ahd(satu), hayy(hidup), gadr(berkuasa), müd (berkehendak), 'alim(mahatahu), sami’łmendengar), basip(maha melihat), mtakallim(berbicara), baqałkekal). Berikut ini adalah nukilan dari isi naskah, pupuhkedua;

Sipat pen amantu bilahi, teegsipun angandd ingAllah, nora na pangranmmanh ammngAlahkang Agung ingkangmumbamisa nengih angganjar pananiksa, ingsakathahipun, tanliyankarsaning Pangran, pan asipat kanavadidan anenggh pan sira YvangSuksma.

(sfat amantu billahi, artinya percaya kepada Allah. Tidak ada Tuhan selain Allah. Dialah yang Maha Agung, Maha Pemberi dan yang berkuasa menyiksa orang yang tidak taat terhadap apa yang diperintahkan oleh Allah. Dia itu Maha Esa atau ahad Alladu sahadat wakidun).

..... ing sipat iku tegese, sipat kayun puniku, ingkang ngurip tegese nenggih , kadirun kang kuwasa, muridun karseku, ngalimun ngawekanana, pan samingun miarsa tegese nenggih, basirun kang tumingal. ... mutakalimun ngandika nenggih, baka iku langgeng tegesira, tan owah-owah karsane ...

(.... Dia bersifat haym yang artinya hidup, qadinun yang artinya berkuasa, mridun yang artinya berkehendak, 'alimmartinya maha tahu, sami'unartinya maha mendengar, basinu artinya maha melihat, mitakalimmartinya berbicara, bagaartinya kekal, ....)

Pada pupuhkedua Serat Waosan Puji juga mengandung ajaran rukun iman dan rukun islam. Adapun rukun Islam meliputi; membaca syahadat, shalat, puasa, zakat dan haji. Sementara rukun iman meliputi percaya pada Allah, Malikat, kitab rasul, nabi dan rasul, hari kiamat, dan takdir. Dijelaskan di dalam teks bahwa kitab seluruhnya berjumlah 104, yang diberikan kepada nabi Adam, nabi Syist, Nabi Idris, Nabi Ibrahim, Nabi D aud, Nabi Isa, Nabi Musa, dan Nabi Muhammad. Jumlah rasul terdapat 311 dan semuanya membawa sjariah sedangkan jumlah nabi ada empat ribu dua laksa. Berikut petikan teksnya:

....tegesipun pracaya ing kitab, tinurunaken nabine, satus papat kehipun, apan bangsa suwara nenggih, Nabi Adam sadaya, Nabi Sis punika, tinurunan seket kitab, Nabi Idris tigang dasa kitab nenggih, Nabi Brahim sadasa. Nabi D awud kitab Jabur nenggih, kitab 
Injil ya ta Nabi Ngisa, Toret Nabi Mungsa mangke, miwah Nabi Panutup, tinurunan dening Ywang Widi, kitab Kuran punika ....

(....percaya kepada kitab yang diturunkan kepada para nabi. Seluruh kitab itu berjumlah 104 buah. Nabi Adam hanya diberi firman suara. Nabi Syits diberi 50 kitab. NabI Idris diberi 30 kitab. Nabi Ibrahim diberi 10 kitab. Nabi D awud diberi kitab Zabur. Nabi Isa diberi kitab Injil. Nabi Musa diberi kitab Taurat. Nabi penutup, yaitu Nabi Muhammad diberi kitab Alquran sebagai penutup kitab....)

Selanjutnya, penjelasan mengenai al-Q ur'an terdapat pada pupuhketiga. Disebutkan tentang nama-nama surat dalam al-Q ur'an serta jumlah surat, ayat, dan nuku Berikut petikan teksnya:

“....cacahesuratingkur'an/ satus patbdas kathahe..."

(... jumlah surat al-Qur'an seratus empat belas ....)

"....keheayatKur'annenggh nemevunematusiku, savidak nenemkathahe, mangkanaklimahing kur'an, sangangleyga punika, pitungenu pitungatus, tigangalasa langkung sanga Kathaheaksara nenggh, tigangkethi tigangnembang patangatuspunjul mangke, neptuningKur'an punika, saleesa enuika, sangangatustigangpuluh, kangkoapingdalemKur'an..."

(.... Lengkap sudah 114 surat dalam al-Qur'an. Banyaknya ayat ada 6666. Kalimat alQ ur'an ada 97.739. Banyaknya huruf ada 330.400. Banyaknya maptuada 10.930. Banyaknya jus ada 11.410. Surat sajadah ada 14 yang dipakai sebgai ayat shalat subuh malam Jumat Banyaknya kitab ada 5.440. Banyaknya nukuk quranada 40.940. Summada 245.200).

\section{Fikih kerukunan dalam Serat Waosan Puji}

Di dalam beberapa pupuhSeratWaosanPuji mengandung ajaran tentang kerukunan di dalam hidup bermasyarakat. Nilai-nilai harmoni tersebut terangkum di dalam alur cerita dan atau tersirat di dalam uraian mengenai falsafah hidup.

Ajaran tentang kerukunan terdapat pada tiga pupuh yaitu; pupuh dhandhanggula yang membahas ajaran Ki Purwadaksina, pupuhdhandhanggrlayang berisi SeratNitisuti, dan pupuh dhandhanggrla yang memuat seat Nitipraja Di dalam ketiga bab tersebut terkandung nilainilai harmoni, meskipun tidak secara langsung dikatakan bahwa isinya mengenai kerukunan.

Nasehat Ki Purwadaksina kepada istrinya tentang falsafah hidup tersebut mencakup tiga hal utama dan baik yaitu; (a) pandhitalami maksudnya halus budi dan berucap lemah lembut, 
Dia tidak pernah menyombongkan diri dan mau bekerja keras. Dia juga bukan seorang munafik. Semua perkataannya menenteramkan hati, (b) panditabgakarana, adalah mencegah hawa nafsu, tidak berbuat dosa dan selalu mendekatkan diri kepada Tuhan. Tidak pernah berhenti melakukan semedi, semua yang dilihat hal yang baik. Tidak ada kawula dan gusti, keduanya telah lebur, dan (c) pandhita umarshandu atau pandhita gunung yaitu berhati bersih dan selalu berdoa kepada Tuhan selama hidup di alam dunia ini. Dia tidak pernah berhenti bertapa dan berdoa mengheningkn cipta. Semua yang dilihatnya nampak indah. Berikut petikan dari teksnya:

“.... kangutamaiku, nglatanakangprayoga, ingjenengekangtigangprakaragusti, ikupagurdkena. Kangnumin pandhita kanglam, kapingkalih ambga karama, pingtiganeiku angger, pandhita umarsandhu...."

(.... Belajarlah kamu pada tiga hal utama dan baik. Pertama yaitu Pandhita Lam, kedua yaitu Pandhita Bga Karana, dan ketiga yaitu PandhitaUmarsandhuatau Pandhita Gunung...)

“.... pandhitalami iku, ingkangsareh wumuseyayi, tanmunk sudi karya, baranglakonipun, tan apadudonkarsanira, savumuseraharja teka lestan, satuhuningpandhita...."

(.... PandhitaLamiitu halus budi dan berucap lemah lembut serta penyabar. Dia tidak pernah menyombongkan diri dan mau bekerja keras. Dia juga bukan seorang munafik. Semua perkataannya menenteramkan hati. Inilah yang dinamakan pandhita yang sebenarnya....)

".... miwahpandhitamarsandhuiki, padhangenakuladaengwikan, kangrakaalonddinge, pandhita lami iku, ingkang sareh wumuse yaji, tan muuk sudi karja, baranglakonipun, tan apadudon karsanira, samumuseraharja tka lestani, satuhuningpandita"

(.... PandhitaUmarsandhuitu berhati bersih dan selalu berdoa kepada Tuhan selama hidup di alam dunia ini. Dia tidak pernah berhenti bertapa dan berdoa mengheningkn cipta. Semua yang dilihatnya nampak indah. Tidak ada yang dinamakan kawula dan gusti lagi).

“....Pandhita Bgjakrana ta yayi, datan peegt anggungmangun tapa, amadhang sarirane, anyegah nepsonipun, datan peegat amangun sei, sasiptanewusnyata, tan anakadulu, sampun waluya sadaya, pangstumetan ana kauxula gusi, uuskaremmarangara."

(.... Pandhita Bga Karana itu mencegah hawa nafsu, tidak berbuat dosa dan selalu mendekatkan diri kepada Tuhan. Tidak pernah berhenti melakukan semedi, semua yang dilihat hal yang baik. Tidak ada kawula dan gusti, keduanya telah lebur). 
Prinsip-prinsip pandhitalami, pandhitaumarsandhudan pandhitabgakaranatersebut sangat kaya makna. Ajaran tersebut merupakan norma-norma etik dalam pergaulan antar umat manusia yang dapat melahirkan harmoni. Karakter halus budi dan berucap lemah lembut adalah prinsip dasar saat seseorang berinteraksi dan berkomunikasi dengan orang lain. Hal ini mirip dengan ajaran Jawa yang lain yakni ajining diri saka inglathi, yang mengandung makna harga dir seseorang tergantung kepada mulut, ucapan dan bahasanya. Oleh karenanya berucap dengan lemah lembut menjadi salah satu prasarat terjadinya dialog yang baik.

Di dalam pupuh yang sama juga dijelaskan tentang lima hal yang harus dijauhi yakni pandhita sipat, limpad, prakkensanghyang nggenthongumosdan tavangbrana Maksudnya adalah; seseorang yang hanya mau hasilnya, gemar bertandang, gemar menggunjingkan orang lain, mempunyai pamrih, dan gemar berhutang. Perilaku yang tidak baik ini tentu saja harus dihindari, apabila tidak maka dikhawatirkan bisa menimbulkan disharmoni di dalam masyarakat. Hubungan antar manusia secara umum menjadi dasar terciptanya harmoni maupun disharmoni di masyarakat.

Di bagian selanjutnya yang memuat Serat Nitisnuti disebutkan beberapa prinsip dalam berinteraksi antar sesama umat manusia. Seratini berisi piudlangberikut ini:

a. Berkata-kata dan menjawab pertanyaan dengan sopan dan ramah. Hati harus dijaga supaya selalu bersih seperti bersihnya rumah yang bercahaya karena semua kotoran yang ada di dalamnya dibersihkan. D emikianlah ibaratnya orang yang telah awas pandangannya terhadapa apa-apa yang dapat menyebabkan rusaknya kesejatian. Maka dari itu hati harus tenang, jernih, dan kokoh menghadapi semua tantangan.

b. Tenggang rasa atau tidak melakukan perbuatan yang tidak baik.

c. D apat memperhitungkan kekuatan diri sendiri. Maksudnya adalah bisa menjaga dirinya agar jangan sampai tergelincir ke hal-hal yang salah. Dia harus mampu menimbang mana yang baik dan mana yang buruk sebelum bertindak. Jangan sampai hidup terombangambing ke sana ke mari tanpa pendirian.

d. Jika sudah mengetahui ilmunya harus hidup rukun. D emikian itu tadi lebih baik.

e. Mau menimba ilmu dari hidup sampai mati. Semua dilaksanakan dengan tekad dan kesungguhan hati tanpa ragu-ragu. Semua dilaksanakan dengan semangat juang yang tinggi, ibarat orang yang maju ke medan laga, berani mengorbankan jiwa dan raga. 
f. Kecerdasan jangan hanya dipakai untuk menyombongkan diri. Semua perkataannya mengada-ada dan sok pintar.

Ajaran nitisuti selanjutnya adalah tentang sifat luhur. Di antaranya yaitu membuat senang hati orang lain, cinta dan kasih pada orang tua, anak yatim, dan fakir miskin, memberi pengampunan pada orang yang telah berbuat salah. Jika bicara tidak ceriwis dan ribut, agar tidak mengganggu orang lain, serta sesuai antara perkataan dan perbuatan.

Serat Nitisruti juga membahas tentang bagaimana seharusnya menjadi raja yang bijaksana, yang tentunya akan dapat menciptakan kerukunan di dalam masyarakat. D isebutkan di dalam teks bahwa menjadi raja yang bijaksana harus bisa menghimpun kasih sayang dan membuat orang lain senang. Selain itu harus bisa mencegah kehendak pribadi dan menciptakan ketenteraman dunia. Menjadi raja juga harus dapat mengupayakan keselamatan orang di dunia, dapat menguasai dan memerintah seluruh rakyatnya. Apabila ada orang yang melakukan kejahatan, raja harus dapat memberikan hukuman supaya merekajera melakukan kejahatan. Lagi pula caranya menerapkan hukuman haruslah seadil-adilnya.

Menjadi seorang rajajuga harus mengerti ajaran Asthabrata, yaitu ajaran Prabu Ramawijaya kepada Gunawan Wibisana. Prabu Ramawijaya menuturkan bahwa ada delapan manfaat yang harus dipelajari, dan tidak boleh dilupakan:

a. Meneladani tingkah laku bumi yang selalu menyebarkan tata krama pada manusia.

b. Meneladani tingkah laku angin yang selalu memberi hukuman pada orang yang melakukan kejahatan. Semua penjahat di dunia dihukum tanpa pandang bulu, walaupun itu keluarganya sendiri.

c. Meneladani tingkah laku matahari yang selalu menuntun hati manusia. Seperti jika menghisap air, diminum pelan-pelan. Jika ada musuh, didekati dengan cinta, diberitahu secara hati-hati dan sopan supaya hilang rasa takutnya.

d. Meneladani tingkah laku rembulan yang selalu menyenangkan semua keinginan manusia dengan kehalusan budinya. Caranya yaitu dengan bercanda tetapi tetap sungguh-sungguh. Perkataannya enak didengar dan memakai pikiran yang halus.

e. Meneladani tingkah laku ombak, yaitu mengingatkan orang lain dengan suara yang berwibawa.

f. Meneladani tingkah laku logam, yaitu mencegah orang yang berbuat jahat. 
g. Meneladani tingkah laku air, yaitu memberi kesejahteraan bagi orang sedunia. Dia tidak lalai dari kewajibannya sebagai raja.

h. Meneladani tingkah laku api yaitu berani maju ke medan perang menghadapi musuh.

i. Sementara di dalam bab selanjutnya, seatnitipraja diterangkan tentang bagaimana perilaku seorang raja terhadap rakyatnya. Dikatakan di dalam teks Serat Waosan Puji berikut ini;

j. A pabila kamu diangkat menjadi raja, jadilah raja yang selalu ingat pada kewajiban. Raja itu seperti matahari yang menerangi, atau air jernih yang mengalir di batu, selalu mencari tumbuh-tumbuhan untuk dihidupkan.

k. Seorang raja harus tahu kapan dia memberi perintah kepada punggawanya (bawahannya). Perintah raja itu seperti mendung dan petir pada musim keempat, yang ditunggu oleh para rakyatnya, bagaikan tumbuh-tumbuhan yang menunggu turunnya hujan dan tetesan embun. Para raja harus seperti itu. Yaitu memberi hadiah bagi orang yang setia dan memberi hukuman untuk orang yang berbuat salah.

D ari ajaran-ajaran yang telah disebutkan di atas, dapat diketahui beberapa norma perilaku baik hubungan antar manusia secara umum, maupun tatakrama dan sifat-sifat yang semestinya ada bagi seorang raja atau pemimpin. Bila hal itu dipatuhi dan atau dilaksanakan dalam kehidupan, maka akan tercipta kehidupan yang tenteram dan baik. Misalnya, tenggang rasa atau tepa sdira adalah ajaran yang kelihatannya sederhana, namun sebenarnya kaya makna. D engan bertenggang rasa maka masyarakat akan saling mengerti dan menghormati, sehingga friksi-friksi akan dapat terhindarkan. Hal ini juga ditopang dengan tatakrama yang lain yakni "ketika berbicara dengan bahasa yang halus dan sopan", ini menjadi kunci bagi komunikasi yang baik di dalam masyarakat, dalam istilah Jawa ini disebut UnggahUngguh (tata krama).

Ajaran tentang perilaku raja juga dapat menjadi pendukung bagi terciptanya kerukunan, misalnya, "raja harus bisa mencegah kehendak pribadi dan menciptakan ketenteraman dunia," pivulang ini secara jelas mengamanatkan kepada para pemimpin untuk mengutamakan kepentingan rakyatnya dan menjadi motor penggerak kedamaian. Selain itu, simbol-simbol dalam ajaran astabrata tersebut juga merupakan jalan lahirnya masyarakat yang tenteram.

Kerukunan antar sesama umat manusia ini dalam istilah Islam disebut ukhumahbashariyah, merupakan satu di antara empatjenis kerukunan yang ada. Sedangkan di dalam Islam Kejawen terdapat istilah nglmudan laku maksudnya peraturan tingkah laku yang yang baik dan mulia 
yang harus menjadi pedoman hidup manusia. Tujuan dari nglmudan lakuini adalah terciptanya hubungan yang selaras antar sesama makhluk hidup di sekitarnya, dengan keluarga, tetangga, dan sesama bangsa. Dasar dari ngelmu dan laku adalah ajaran-ajaran agama (Hariwijaya, 2004, 204). D engan demikian, dapat dimengerti bahwa ajaran keagamaan yang ada di dalam teks dan juga nilai-nilai kerukunan tersebut menjadi bagian yang tak terpisahkan di dalam konsep masyarakat Islam Jawa.

\section{Integrasi nilai Islam dan Jawa dalam Serat Waosan Puji}

Menilik isi dari Serat Waosan Puji yang beragam sebagaimana telah disebutkan dalam bab sebelumnya, maka naskah ini dapat dikatakan sebagai naskah campuran antar bermacam teks, pun demikian pula dengan pesan-pesan yang dikandungnya. Terdapat beberapa teks yang membahas ajaran-ajaran keagamaan, adapula yang memaparkan tentang falsafah Jawa, serta ada yang menggabungkan antar keduanya yakni antara pesan Islam dan Jawa menyatu di dalamnya.

Ketiga hal tersebut menjadi pertanda bahwa pesan di dalam naskah ini merupakan wujud akulturasi antar dua norma besar yakni Islam dan Jawa. Wujud integrasi tersebut terlihat di dalam penggunaan doa dan tradisi pembuatan makanan tertentu, juga tradisi mempersembahkan makanan bagi para nabi dan wali, serta yang lainnya. Hal ini dapat dipahami bila merujuk sejarah masuknya Islam ke tanah Jawa yang dibawa walisongo dengan jalan damai dan melalui pintu budaya, maka Serat Waosan Puji ini menjadi salah satu cermin tentangnya. Berikut ini beberapa petikan teksnya:

“.... Panpunika wontenpüi mali, apanwiniraos dentulisingapemniyose, bakdasalat nulyabinukti, savabipunug, baguscahyanipun Assalamu"

(.... Selanjutnya ada suatu doa lagi. Jika doa ini ditulis di atas kue apem, kemudian dimakan sesudah mengerjakan shalat, akan mendapatkan manfaat yang besar dan bersinar cahaya mukanya. D oanya yaitu : Assalamu)

\section{"Al-alimu pan punika wonten asma malih, kalammpunangwong nandhangsakit barangsakite, panasadhemlawanngilunenggh anulisa agis ingcadhonganmau"}

(Apabila ada orang yang terkena penyakit panas, tulislah doa berikut ini di atas daun. Kemudian rendamlah daun itu ke dalam air secukupnya. Lalu percikkan air itu kepada si 
sakit ke seluruh badannya sambil memohon kepada Tuhan. Insya Allah akan segera hilang penyakitnya. Adapun doanya yaitu : Al Alimu)

Pembacaan asmaulhusna (nama-nama baik Allah) yaitu al-salamu, al-alimu dan ya ghafun merupakan tradisi bagi umat muslim, namum menuliskan asmaul husnatersebut di atas kue apem atau daun adalah tradisi Jawa. Di sini terlihat adanya dua nilai yang saling bertemu dan bahkan saling menyatu menjadi satu ritual. Selain itu, di dalam teks Serat Waosan Püi juga terdapat anjuran mempersembahkan jenis makanan tertentu kepada para nabi dan wali pada hari-hari tertentu. Berikut ini petikan teksnya:

"Dina akat pinüia nijin, pujerira ya Kayumu ika, angsal limangatus mangke, ldema unipipun, Nabi Adamingkangdarbeni, lakune ceghhkinang sadinten sadalu, yenAkadlakunesurya, kang numksa sadina lawansaweng, maldkat limangldksa"

"Dina akat ing aturan bukti, sega gdong peedipun ayam lisir wean ing wanaine, yen lumungan puniku, pama-pama ja nganti lali, yen kasahleisaha, savabepan agung rahayu sabarangkarsa, anengmarga panca baya wus kavuni, sangking pangkesaning vang"

(Hari yang pertama yaitu Hari Minggu. Hari ini mempunyai pahala limaratus banyaknya. Hari Minggu adalah hari kepunyaan Nabi Adam. Pada hari ini terdapat pantangan makan sirih sehari semalam. Hari ini dijaga oleh 50.000 malaikat.)

(Pada hari Minggu dianjurkan menyajikan makanan yang berupa nasi golong dan peed ayam di waktu subuh. Jika bepergian di hari itu harus dengan cepat-cepat supaya terhindar dari mara bahaya).

Tradisi mempersembahkan makanan adalah tradisi Jawa yang memang sudah ada sebelum Islam masuk ke wilayah tersebut dan terus berlangsung hingga waktu sekarang. Namun pada perkembangannya telah dimodifikasi dengan ajaran Islam. Misalnya tradisi selamatan dengan menyediakan makanan dan di tutup dengan doa-doa.

Serat waosan puji ini telah berupaya menyandingkan dua ajaran Islam (syariah) dan Jawa dalam satu kumpulan teks. Tidak ditemukan pertentangan di dalamnya, bahkan lebih cenderung kepada saling melengkapi. Hal ini nampak pula pada satu pupuhyang menampilkan "KidungRumksaingWeng", dikatakan kalau kidung ini dibaca akan mendapatkan manfaat seperti lepas dari penyakit, lepas dari celaka gangguan setan, lepas dari pencuri, lepas dari semua perbuatan jelek, lepas dari penjarahan pencuri dan semua orang akan berbelas kasih. 
Kidung ini menyebutkan beberapa nama nabi sebagai penunggunya, di antaranya adalah nabi Ibrahim, Nabi Isa, Nabi Muhammad, Nabi Ismail, Nabi Luth, Nabi Idris, Nabi K hidzir dan lainnya.

Islam Jawa yang berpusat pada ajaran sufi bahwa antara kemanusiaan dan ketuhanan antara hamba (kawula) dan Tuhan (gusti) diterangkan di dalam cerita Ki Purwadaksina berikut ini:

Kata Ki Purwadaksina, "Maskawin Allah itu artinya bertemu dengan rohullah yaitu hidup dalam rasa sejati. Maskawin arasdan kursi itu artinya Nur Muhammad. Maskawin pria dan wanita, itu bertemunnya jasad dengan nyawa. Maskawin cahaya-bintang, itu bertemunya sumsum dan tulang. Maskawin ilmu, yaitu bertemunya daging dan darah, yang menyebabkan jantung berdetak. Maskawin bumi-langit, itu bertemunya otak dengan sirullah Maskawin siang-malam yaitu bertemunya hitam dan putih mata. Itu tadi dinamakan ru'yat, seperti bertemunya kawula dan gusti yang menjadi satu dalam rasa dan wawasan. Maskawin surganeraka itu bertemunya nafsu dan budi. Ini dinamakan manunggalnya pengetahuan baik dan buruk. Semua menjadi satu rasa."

Nyi Purwadaksina bertanya, "Bagaimana semua menyatu dalam rasa?" "Semua menyatu dalam suhut, satu pandangannya. Banyak wujud yang memperoleh kemuliaan sejati di sana," kata Ki Purwaduksina.

\section{Penutup}

D ari pemaparan pada bagian sebelumya dapat disimpulkan bahwa Naskah Seat Waosan Puji dalam kondisi baik, teks dapat dibaca dengan jelas, ditulis dengan huruf dan bahasa Jawa. Naskah ini berisi beberapa macam teks, merupakan kumpulan beberapa nukilan teks dari beberapa naskah lain (semacam primbon). Berisi tentang doa-doa; rukun iman, rukun Islam dan tauhid; nama-nama surat dalam al-Qur'an; ajaran Ki Purwadaksina; nasehat Rasulullah kepada putrinya, ramalan-ramalan, firasat dan watak manusia, nama-nama makhluk halus, hari-hari baik, serat Niti Snti, dan SeratNitipraja Ajaran tentang kerukunan terdapat pada tiga pupuhyaitu; pupuhdhandhanggllayang membahas ajaran Ki Purwadaksina, pupuh dhandhanggula yang berisi Serat Nitisniti, dan pupuh dhandhanggula yang memuat sarat Nitipraja. 
Di antara ajaran tersebut adalah; (1) falsafah hidup mencakup tiga hal utama; pandhita lam, pandhitabgjakarana, dan pandhitaumarshanduatau pandhitagunung (2) lima hal yang harus dijauhi yakni pandhita sipat, limpad, prakken sanghyang nggenthongumos dan tawangbrana (3) ajaran dalam Seat Niti Snti; Berkata-kata dan menjawab pertanyaan dengan sopan dan ramah, tenggang rasa, tidak sombong dan lainnya, (4) ajaran asthabrata, (5) prinsip-prinsip bagi seorang raja. Di dalam serat Waosan Puji terdapat integrasi dan akomodasi antara nilainilai Islam dan Jawa.

\section{Daftar Pustaka}

Abdullah, I. Konstnuksi danReproduksi KdoudayaanYogyakarta: Pustaka Pelajar, 2007.

Amin, D, "Sinkretisme dalam Masyarakat Jawa," dalam Amin, D. (ed.). IsamdanKdaudayaan Jawa Yogyakarta: Gama Media, 2000.

D aeng, H.J. Manusia, Kdudayaandan Lingkungan Yogyakarta: Pustaka Pelajar, 2005.

Damami, Mohammad dkk. Kanjeng Kyai Surya Raja, Kitab Pusaka Kraton Ngayogyakarta Hadiningat. Yogyakarta: Y K II bekerjasama dengan IAIN Sunan Kaligaja, 2002.

Damami, Mohammad, "Islam dan Keraton Yogyakarta; Aspek Normatif dan Historis Islam dalam Naskah", dalam D amami, Mohammad dkk. Kanjeng Kyai Surya Raja, KitabPusaka Kraton Ngayogyakarta Hadiningat. Yogyakarta: Y K II bekerjasama dengan IAIN Sunan Kaligaja, 2002.

D epartemen, Agama. Komilas PeaturanPeundangan-UndanganKerukunanHidupUnat Beragama edisi keujuh Jakarta: Departemen Agama dan Badan Litbang Agama dan Diklat Keagamaan Puslitbang Kehidupan Beragama Bagian Proyek Peningkatan Pengkajian Kerukunan Hidup Umat Beragama, 2003.

Farida, Jauharatul, "Internalisasi Islam dalam Arsitektur Jawa”, dalam Amin, D. (ed.). Isam dan Kdoudayaan Java. Yogyakarta: G ama Media, 2000..

Faruk. Pengantar Sosidog Sastra, dan Strukturalisme Geneik sampai Post Strukturalisme Yogyakarta: Pustaka Pelajar, 2010.

Geertz, Clifford. Pditik Kedudayaan Yogyakarta: K anisius, 1992.

Geertz, Clifford. Pengtahuan Ldkal. Yogyakarta: Merapi, 2003.

Hanafi, Hasan, "Etika Global dan Solidaritas Kemanusiaan Sebuah Pendekatan Islam", dalam Hanafi, Hasan dkk. Isamdan Humanisme, Aktualisasi HumanismeIdamd Tengah KrisisHumanismeUnivesal. Yogyakarta: Pustaka Pelajar, 2007.

Hanafiah, D. MdayuJJana; CitraBudaya danSgarahPalembang Jakarta: Raja G rafindo Persada, 1995. 
Hariwijaya. IdamKgjanen Yogyakarta: G elombang Pasang, 2004.

Harrison, L.E \& Huntington, S.P. (ed.). Kebangkitan Pean Budaya; Bacaimama Nilai-nilai Membertuk KemajuanManusia. Jakarta: LP3E S, 2006.

Ismawati, "Budaya dan Kepercayaan Jawa Masa Pra-Islam", dalam Amin, D. (ed.). Isam dan Kebudayaan Java Yogyakarta: G ama Media, 2006.

Jandra, "Model Pergaulan dalam Masyarakat pada Serat Sangulara dan SeratJoko Pengasih", dalam Jandra dan Suryo, Joko. Modd Kdidupan Bemasjarakat dalamKhasanah Budaya Keaton Yogjakarta Yogyakarta: Y KII bekerjasama dengan UIN Sunan Kalijaga, 2007.

Kaplan, D \& Manners,R.A. Teeri Budaya Yogyakarta: Pustaka Pelajar, 2002.

Kodiran. Kebudayaan Jawa. D alam Koentjaraningrat. (Ed). Manusia danKdudayaandi Indo nesia. Yogyakarta: Djambatan, 1993.

Koentjaraningrat. JavaneseCulture Singapore: Oxford University Press, 1985.

Koentjaraningrat (ed). Manusia dan Kdudayaan di Indonesia. Yogyakarta: Djambatan, 1993.

Kuntowijoyo. Budaya dan Masjarakat. Yogyakarta: Tiara Wacana, 1987.

Madjid, Nurcholis. IdamAgama Kemanusiaan, MerbangunTradisi danV is BanuIdamIndonesia Jakarta: Paramadina, 1995.

Mudzhar, Muhammad Atho', "Tantangan Kontribusi Agama dalam Mewujudkan Multikulturalisme di Indonesia", Jumal Hammi, Volume III, Nomor 11 Juli-September 2004.

Muhaimin, AG. Damai di DuniaDamai untuk SemaPespoktif Berbagai Agama Jakarta: Puslitbang Kehidupan Beragama Badan Litbang dan D iklat Keagamaan D epag RI, 2004.

Munawar, S.A.H. Fikih Hubungan Antar Agama Jakarta: Ciputat Press, 2005.

Noeradyo, Siti Woerjan Soemadiyah. KitabPrimbon Bealjemr Adammakna. Yogyakarta: CV Buana Raya, 1994.

Purwadi. KitabJana Kuno Yogyakarta: Pinus book publisher, 2009.

Purwadi. Filsafat Jana; Refleks Butir-butir Kdijaksanaan Hidup untuk Mencapai Kesempumaan Lahir Batin Yogyakarta: Cipta Pustaka, 2007.

Purwadi. Ramalan ZamanEdan Ronggonarsito Yogyakarta: Media Abadi, 2004.

Purwadi. Histary of Java; Loal WisdomDesciption SinceA nient MataramtoConempraryEra. Yogyakarta: Tanah Air, 2007.

Rahardjo, T. Mengharcgi PebeebanKultural; MindfulnessdblamKommijkas AntarEtnis Yogyakarta: Pustaka Pelajar, 2005.

Renard, John. Dimens-Dimens Islam D epok:Inisiasi Press, 2004.

Roqib, Moh. Harmmi dalamBudaya Java, Dimens Edukas dan Keadilan Gender. Purwokerta: STAIN Purwokerto Press, 2007. 
Sachedina, A. Beeda tapi Stara; Pandangan IslamtentangNon-Idam Jakarta: Serambi, 2004.

Simuh. SufismeJana; Transfomas Tasanuf IsamkeMistik Jana. Yogyakarta: Bentang Persada, 1999.

Soekanto, S. Bdъerapa Teen Sosidøj tetangStruktur Masyarakat. Jakarta: Raja Grafindo Persada, 1993.

Sofwan, R. \& Wasit \& Mundin (ed). Isamisas di Java, Walisongs Penydbar Islamdi Jawa, menunt Penuturan Babad Yogyakarta: Pustaka Pelajar, 2004.

Sofwan, R., "Interelasi Nilai Jawa dan Islam dalam Aspek Kepercayaan dan Ritual”, dalam Amin, D. (ed). Idamdan Kdudajaan Java. Yogyakarta: G ama Media, 2000.

Steenbrink, K. KawandalamPetikaian; KaumKdonial BdandadanIsamdi Indonesia 1596-1942. Bandung: Mizan, 1995.

Sudharto, "Interelasi Nilai Jawa dan Islam dalam Pewayangan”, dalam Amin, D. (ed.). Isam dan Kdoudayaan Java Yogyakarta: G ama Media, 2005.

Suharso \& Retnoningsih. KamusBesar BahasaIndonesia edis Lux. Semarang: CV.Widya K arya, 2005.

Suryo, Djoko, "Serat Ngabdul Suka sebuah Ajaran Nilai-Nilai Etika Moral Sosial-Keagamaan bagi Calon Raja dan Pemimpin Masyarakat", dalam Jandra dan Suryo, Joko. Mood Keiidupan Bemasyarakat dalamKhasanah Budaya Keraton Yogakarta. Yogyakarta: Y K II bekerjasama dengan UIN Sunan Kalijaga, 2007.

Usman, Fathimah. Wahdatal-Adyan; DialogPluralismeAgama Yogyakarta: LkiS, 2002.

Veeger, K.J. Reelitas Sosial; Refleks Filsafat Sosial atas Hubungan IndividurMasjarakat dalam Cakrawala Sgarah Sosidog், 1986.

Woodward, Mark. R. IsamJama, KesaldhanNomatif vesus Kd๖atinan Yogyakarta:LkiS, 1999. 